\title{
Maximizing Garbage Clinical Insurance Adoption Through Communication Network
}

\author{
Aulia Suminar Ayu \\ Communication Department \\ Universitas Selamat Sri \\ Kendal-Jawa Tengah, Indonesia \\ aulia.sumi@gmail.com
}

\begin{abstract}
Innovation is an idea that considered as new thing by its adoption unit. Although trash bank has quite common, and easily to find in Indonesia and other countries, but garbage as scheme to pay health expense can consider as something new. Garbage Clinical Insurance as innovation can be accepted or rejected by system due to their novelty. Through communication network analysis, this research aim to formulating strategic plan to maximizing adoption rate of Garbage Clinical Insurance. As mixed method research, the theories that used here is diffusion of innovation, convergence model of communication, strength of weak ties, and health belief model. This research using total sampling that consist of 101 families in neighborhood area (RT01/RW12), Bumiayu Urban-village (kelurahan), Malang. Primary data collecting technique employed is sociometry survey, in-depth interview, and observation. Sociogram and some data count analysis were using Ucinet 6.0. Generally, network cohesiveness indicates characteristic that closed from new information or innovation. Such an anomaly, the result shows that in-cohesive network also has closed characteristic. In the other side, people who live surround Bumiayu Clinic don't consider health issue as important thing yet, that shapes low awareness of Garbage Clinical Insurance. Decentralized pattern characteristic can use interpersonal threshold, individual counselling. But centralized approach (group counselling) can be used too as formulas to maximizing its adoption rate.
\end{abstract}

Keywords-communication network analysis; interpersonal threshold; garbage health insurance; strength of weak ties; decentralized network; health belief model

\section{INTRODUCTION}

Health is a basic right for all citizen in Indonesia. Any citizen, rich and poor, has the right to live healthy and get health care from the state. The obligations to be made by the state are clearly stated in the 1945 Constitution (UUD 1945) article $28 \mathrm{H}$ paragraph 1 below:

"Every person has the right to live a prosperous physically and mentally, to live, and to get a good and healthy living environment and be entitled to health care".

The coverage of health care insurance is realized by the Government of Indonesia through the Ministry of Health in the form of JKN (Jaminan Kesehatan Nasional- National Health Insurance). JKN is affiliation of the Askes (Asuransi Kesehatan- Health Insurance) and Askeskin (Asuransi Kesehatan Miskin- Health Insurance for Poor). Today, those terms change into Badan Penyelenggara Jaminan SosialKesehatan (BPJS-Kesehatan, Social Security AdministratorHealth Division) and their users divide into two: PBI (Penerima Bantuan Iuran - Beneficiary) and Non PBI (Nonbeneficiary). Based on https://www.bpjs-kesehatan.go.id, the official website of BPJS Kesehatan per July 1st, 2017, there are 178.384.288 citizens that registered from 293.7 million population, and 109.108.419 of them are beneficiary. Even $61,16 \%$ who has been registered are for poor people, but there are still a lot of them that not covered yet by BPJS Kesehatan.

There is an innovation that covered health care insurance for poor that using garbage as scheme to pay their monthly subscription fee. This garbage clinical insurance is a product of CV. Indonesia Medika which founded by Gamal Albin said, MD. His idea turning waste from problems into a potential health financing fund is somewhat influenced by his surrounding environment. Malang is a city that has a waste bank managed directly by their citizen and synergize with the Malang Government. Initially, 'Malang Waste Bank' (Bank Sampah Malang) was initiated by environmental activists by showing that the waste can be converted into a financial income. The support coming from the city government of Malang (Mayor - Peni Suparto, Hygiene and Gardening City Service), PKK, and local residents make garbage bank can keep going until now.

Malang Waste Bank has the highest garbage purchase price compared to other garbage collection sites. For this reason, CV. Indonesia Medika cooperate with Malang Waste Bank at the beginning of the Garbage Insurance Clinic. Collaboration between Malang Waste Bank and CV. Indonesia Medika limits to determine the price of waste that will be converted into insurance funding.

Garbage Clinical Insurance exchange garbage to get basic health services equivalent clinical doctor services. It means, CV. Indonesia Medika do environmental communication. This is because $\mathrm{CV}$. Indonesia Medika needs to teach the people to sorting waste. Robert Cox in Environmental Communication and Public Sphere (2006, 11-13) divides the concept of environmental communication into two functions: the first is pragmatic, such as educating, inviting to alert, persuade, mobilize and help overcome environmental problems [1]. The second function is constitutive, which is at a deeper level, such as building understanding and encouraging the emergence of environment awareness. 
That way, Garbage Clinical Insurance by CV. Indonesia Medika promotes health, environmental communication as well as doing social insurance business. Social insurance refers to a program that can help people regardless of one's income level [2]. While the definition of health promotion based on WHO [3]:

"Health promotion as a process of enabling people to increase control over and to improve their health" .... as a mediating strategy between people and their environment, synthesizing personal choice and social responsibility in health".

Health promotion main objectives are health behavioral change, increasing knowledge, attitude, and action about their health. Behavioral changes will occur if someone benefits when they change their behavior from their old behavior. The combination of health promotion, micro-scale social insurance and environmental education shows from Garbage Clinical Insurance that don't give health insurance for free. When they making their service not free, it teaches people being more aware about their environment. The community is obliged to care about the environment by their effort of sorting waste to get health service.

Garbage Clinical Insurance concept can be classified as an innovation because it combines health promotion, micro scale health insurance, and environmental communication. Innovation is an idea, practice, or object considered new by humans or other adoption units [4]. Novelty nature of innovation create uncertainty for their (potential) adopters, so innovation can be accepted or rejected by their adoption units.

User number of Garbage Clinical Insurance is quite up and down. In the beginning of the Garbage Clinical Insurance establishment in 2010, the clinic only runs for six months, and then vacuum for some periods of time (Redaksi Radar Malang, December 13th, 2013). However, in March 2013 and GIC formally becomes a CV; The number of its customers reached 300 people. In 2014, customers of garbage insurance clinics doubled up to 700 customers which spread across 5 clinics in district of Malang city. A year later, the 5 clinics have been reduced to one clinic, Garbage Clinical Insurance in Bumiayu, Malang and 'only' has 203 customers (source: GCI Indonesia Medika Customer Data, May 2015).

There are 78 international and national media that covering Garbage Clinical Insurance (GCI Indonesia Medika Promotional Data, May 2015). With such a number media coverage, as an innovation, Garbage Clinical Insurance is very interesting to be studied. First, from 15,770 residents of Bumiayu village (Bumiayu Village Monograph, 2014: 1) spread in $6 \mathrm{RW}$, user penetration is only 306 or $1.9 \%$ percent. Concentrated only at RW 05. An innovation being accepted/rejected is not just a communication problem during innovation-related socialization. The high publicity in mass media is also not a significant factor that makes an innovation acceptable / rejected in society. Rather, factors such as the characteristics, attitudes, motivations of the community to share among themselves are instrumental in the acceptance of innovation [5].
Instead of massive coverage of regional, national, and international media, the adoption rate of Garbage Clinical Insurance is unstable on the contrary. Through communication network analysis, researcher try to: (1) examine what factors and reasons makes the Garbage Clinical Insurance user decide to adopt the innovation, (2) furthermore, through communication network analysis, researcher wants to know if there are focal/influential person(s) who can be agent of change and what is the best approach based on network characteristic to increase the adopter number of Garbage Clinical Insurance.

This research aims to provides description of adopter communication network pattern along with network sociometric index in adopting garbage insurance and residents of RT02 / RW05 Bumiayu, Malang to develop a strategy of increasing innovation diffusion and adoption rate. This is because the analysis of communication networks can be used as a guide to intervene or change effectively. Network analysis can answer practical questions "from where changes should start at" or "from whom changes can begin".

\section{ReSEARCh MethoD}

\section{A. Communication Network Analysis: Sociometry Survey}

Primary data collection is done by conducting a sociometric survey. Sociometry is a method of collecting quantitative data about communication patterns among individuals in the system (Rogers \& Kincaid, 1981: 91) in the form of respondent identity questions and indicating where information is obtained and share. Sociometric survey collecting data using ascending method, asking directly to the person directly related about their interpersonal network they have [6]. The fundamental approach in this technique is characterized by targeted sampling. Researchers describe a set of systematic steps used to identify the population-related issues and begin to organize social networks from informants. First of all, researchers used the epidemiological method to describe areas that can be used to collect data. Next, use the thick description to describe population characteristics. Furthermore, researchers use temporary data that have been obtained to develop questions and required a flexible approach that can respond to changes in information.

The sociometric survey was conducted with questionnaire instruments with structured questions. Related to the name of the actor, there are two kinds of questions in the communication network analysis method; free recall and roster [7]. Rooster is a closed question about the names of actors involved in their network of names, but less efficient for large samples. The question format used in this research is free recall or the respondent is free to mention the names that exist in their network. Furthermore, the number of actors involved in communication networks is limited to a maximum of three names per actor. If the mentioned actor that involved not being limited by number, it will be a very long list and complicate data processing.

In this research, the sampling method that being used is Sampling Intact Systems (SIN). This sampling method also known as total sampling or census, uses one/more systems as samples. Each member of the system is the respondent who has 
certain criteria to be sampled. SIN has its own advantages as a sampling method because the characteristics of respondents and people who are in interpersonal relations are both interviewed.

Criteria in this research is the area around Garbage Clinical Insurance Indonesia Medika, Bumiayu RT 02 / RW 05 chosen as sampling area because it located directly opposite from clinic and has the highest number of adopter. RT 02/RW05 has 24 from 55 family members adopter. Total sampling in here means, researcher taking data from whole RT02/RW05 residential area, that is 101 family members that consist of 77 non-adopters and 24 adopters.

Sampling begins with making a shopping list. The shopping list is a list of needs that includes sample criteria and contains from a list of target population members. Shopping list in this study is divided into two parts criteria: (1) adopters, and (2) Non-adopters. Non-adopters themselves will be divided into two kinds: the first is a person who has not joined yet but still consider its decision; Second: a person who has no intention to join or rejecting the innovation. For adopter, the name that will on interview list is the name of the insurer. Selection of these criteria by hypothesis that they are more informed about insurance than name of the other being insured.

The next criteria are the head of the family. This is motivated by the data of Garbage Clinical Insurance customers on the initial findings of the interview. While the selection of criteria on this one is based on the hypothesis that the husband/head of the family is an influential figure in the family who can share information to family members. The sociogram will be mapped based on these criteria.

While for secondary data obtained by in-depth interviews related parties (CV Indonesia Medika), observation, documentation of the RW (sub-sub-district) and related kelurahan (sub district), as well as from literature study.

The researcher hypotized that (1) the residents communication network is cohesive, so it has characteristic that closed from new information or innovation.

\section{RESULTS AND DISCUSSION}

\section{A. Communication Network Analysis: Society and Adaptor} Characteristic

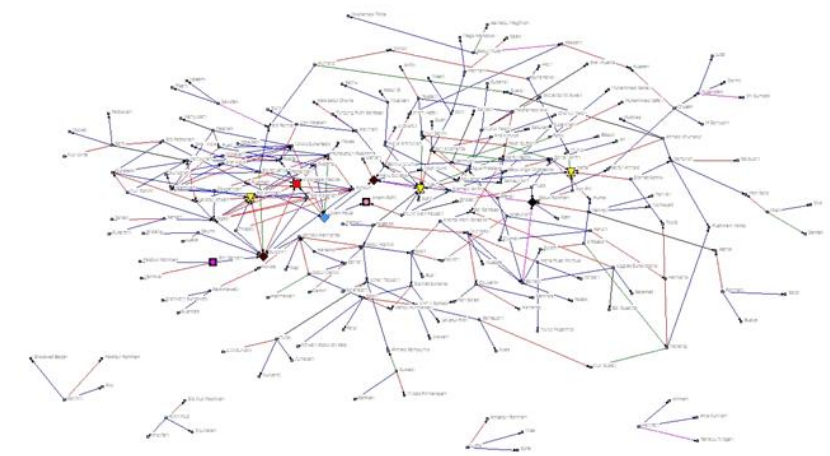

Fig. 1. Complete Network-Sociogram of RT02/RW12 Kelurahan Bumiayu, Malang
System-level analysis describes the whole network, analysis at this level serves to see the characteristics and structure of the network, which consists of the size, system average connectivity, distance, diameter to see the cohesiveness of the network. Openness of the system to see the nature of networks related to innovation / openness to new information. Centrality looks at network patterns. Diversity (diversity) to see the character of the network psychographically.

TABLE I. NETWORK MEASUREMENT OF RT02/RW05

\begin{tabular}{|l|l|}
\hline Density & 0.006 \\
\hline Diameter & 16 \\
\hline Average Distance & 6.495 \\
\hline Centralization & 0.0034 \\
\hline
\end{tabular}

The result shows that the density combination (0.006519), distance (6.4 actors), diameter (16 steps) indicated that the RT02 / RW05 network was not cohesive. While the centrality value $(0.365)$ indicates that the network is decentralized. While the openness of the system (0.0009694) shows a fairly closed system of innovation.

Size and density are part of indicator of network activity. This is because both are used as a comparison between the number of members in the network with the number of relationships that appear. Density describes the communication intensity between members. Size of complete network doubled from the respondents itself (from 101 up to 223 actors) due to there are many families that consist of extended family in this neighborhood. Extended family is a condition when a family besides the core family, there are mother/father/daughter/son in law, cousins or other relatives that include in their family. So, it affects the communication pattern in this network, that generally taking among peers and it means not on the same family role (head of family, wife, daughter/son).

Complete network density of 222 actors with the number of relations as 319 is 0.006509 . A network is considered to have a strong relationship if the network is cohesive. The simplest conceptualization in viewing social network cohesion is through density. Density and reciprocity are inseparable from one another to see the cohesiveness of the network, this is because the more actors are connected and are communicate in two-way direction, it means the higher the cohesiveness it holds [8]. As the size of an actor increases in the network, the density will generally be lower. This is related to the time and energy required for the actors to connect with each other. Therefore, density is usually used to measure small group dynamics.

The researcher assumes that Rukun Tetangga is still in the smallest group in the population structure, so density can still be used to measure network cohesiveness. A network that has a high density usually has a network that is in the form of locking (interlocking). Therefore, new information (innovation) will be difficult to get into it and getting more closed. In other words, the effect of the system on the individuals in it is quite strong. 
Instead of that, researcher assumed a hypothesis that the closed nature possessed by the residents of RT02/RW05 was due to their cohesive form of communication network, characterized by high density and reciprocity. So, the message related to Garbage Insurance lost its influence compared to the influence that exist in their own network. This hypothesis was built based on customer data in the RT which only amounted to 24 families of 125 families, or less than one fifth, a small enough figure to see the existence of Clinic of Garbage Insurance which has been stepped on 2 years.

However, this hypothesis is being indisputable because there are sociocultural-economic factors that also affect beyond the nature of RT02/RW05 community communication network patterns. From the preliminary data shows that RT02 / RW05 residents who were not join Garbage Clinical Insurance (GCI) yet, are not interacting with each other, discussed, influenced their interest/disinterest, or their attitude toward GCI topic. It means, there are no influential person who persuade RT02 residence to not adopt GCI. As we can see from figure 1, the closeness character of RT02 network are not because of the system effect that are interlocking into focal individual or having high density. The sociocultural-economic factors that can explain the most vividly about the closing nature of RT02 / RW05 residents to the Garbage Insurance innovation are education and employment.

Rogers and Kincaid [9] summarized from 120 studies that adopter characteristic toward innovation generalized under:

- Socioeconomic status

- Personality variables

- Communication behavior

However, in this study, researchers wanted to give a brief description that the level of education (that under the socioeconomic status indicator) has a relative influence. Based on the data obtained, the level of education of the people who have become the customers of Garbage Clinical Insurance and the resident who dont join yet are at the same level of education (not having any formal education, elementary, middle, and high school graduates).

TABLE II. EDUCATIONAL DIVERSITY

\begin{tabular}{|l|l|l|l|l|}
\hline & \multirow{2}{*}{$\begin{array}{c}\text { Educational } \\
\text { Diversity }\end{array}$} & \multicolumn{2}{|c|}{ N } & \multirow{2}{*}{ Total } \\
\cline { 3 - 4 } & \multicolumn{1}{|c|}{$\begin{array}{l}\text { Non-adopter } \\
\text { Not having formal } \\
\text { education }\end{array}$} & 2 & 1 & 3 \\
\hline 2 & Elementary & 45 & 15 & 60 \\
\hline 3 & Middle school & 12 & 4 & 16 \\
\hline 4 & High School & 12 & 7 & 19 \\
\hline 5 & Diploma & 1 & - & 1 \\
\hline 6 & Bachelor & 2 & - & 2 \\
\hline & & & 101 \\
\hline
\end{tabular}

The diversity occupation of RT 02 / RW05 is quite even, more than half of them work as traders / entrepreneurs. The work ethic as a trader owned by RT02 / RW05 residents is slightly influenced by the work ethic of the Madurese who live in their midst. In Kelurahan Bumiayu existing 6 RWs, RW 05 (where the research taken place) is a RW that has no area of rice fields and plantations. Whereas in other RW, the settlement is dominated by large-sized houses and yard. On the contrary, seen on RW05, especially on RT02. Settlements look dense and crowd, although the size of the house cannot be said as small as urban settlement in the present day.

The Madurese immigrants who have been around two generations in this area have a job as a trader. These native Madurese who have become permanent residents have a very persistent work ethic in making a living as a trader. the surrounding people who originally worked as farm laborers and farmers began to turn the profession into a trader due to farming depending on the season, while traders can do the job anytime. Their persistence in trading is reflected in observational data obtained by researchers in the field that they are still selling even on holidays, and always optimize the time to earn money, such as holding a food bazaar (spill market) on the highway around RT during Ramadan. So, do not exaggerate if the principle of Madurese "bantal omba 'asapo'angin", (sleep cushioning by wave and wind as blanket). The metaphor illustrates that Madurese (almost) for twentyfour hours in a working condition and never giving up.

This is what makes RT 02 / RW 05 more individualistic and only communicates with the nearest neighbors, due to their daily lives as traders whose days are still selling, and how to optimize the time to earn money. So, they are become more individualistic on their communication pattern.

\section{B. Communication Convergence}

The reasons stated by the residents who have not adopted the Garbage Clinical Insurance besides the 'complicated' are the amount of waste that is lacking, didn't feel anything wrong with their health and if they done routine checking will cause fear because the disease is known, or do not have time. This is called selective perception.

The form of rejection, evasion, and not seeking further information related to this Garbage Insurance is one form of selective exposure. Unconsciously or consciously, the individual avoids messages that are contrary to his predisposition and values. This trend is known as selective exposure [10]. And the values it embraces are to avoid things that can complicate themselves in the future, so as to emerge the reasons as have been put forward. So, it is not surprising when the researchers ask if they know of the existence of the Garbage Clinical Insurance, they answered, but they chose not to discuss it because it is not interested, because it is not in accordance with their values. Settlement types adjacent to each other make the residents of RT02 / RW05 know in passing. When they are asked if they know about the garbage insurance clinic or the Bumiayu Clinic? Only 12 out of 77 residents answered "do not know". Meanwhile, if they answered "know", with uniform answer reads "just know it because there are officers Indonesia Medika around," and "know because there is a clinic at a crossroad near the house".

While other reasons that appear is known as selective perception. If selective exposure is the tendency of an individual to assume a message exists or not based on the attitudes and values it embraces. Then selective perception is 
the tendency of individuals to interpret the message in accordance with what he followed. Though they do not know how to manage the Garbage Insurance is just enough to submit a photocopy of family registered card and ID card only, they have assumed it is a complicated thing.

In the convergence model, the error in perceiving the Garbage Insurance is called Pluralistic Ignorance. Pluralistic Ignorance is the degree that individuals perceive actions / behavior of others wrongly [9]. Communication in a convergence model is an ongoing process (no beginning and end) and is understood as a relationship between the parties giving each other meaning to one another [9]. Although it results in a form of pluralistic ignorance, communication is not necessarily deemed to have failed, because communication is a process.

At the physical level and psychological level, including into the intrapersonal process. Pluralistic Ignorance that occurs because they associate the process of Garbage Insurance management Jamkesmas and Jamkesda process that takes a long time. This is because at the physical level they have not received enough information related to Garbage Insurance. So that at the social level they achieve a common understanding and approval of "disagreement and disagreement" with the innovations offered by Indonesia Medika Team related to their health insurance.

\section{Interpersonal Threshold and Strategic Planning toward Maximizing Adoption Rate}

In RT02 / RW05, community communication networks are decentralized. This decentralized network arises from a centralized value of 0.3665 (still far from number one) or from a network form, whether the network is centered significantly to a particular individual. Based on the data and overall network sociogram presented above, on the RT02 communication network no star leaders or opinions are significantly designated by the system members.

A person can be said to be an opinion leader if at least chosen from $10 \%$ of the system members [11]. While the elected 'focal individual' has only $8 \%$ of the voting rights as stars, and $4 \%$ as opinion leaders, they do not qualify as opinion leaders. Therefore, an approach model that uses opinion leaders as a means of innovation of diffusion cannot be done (although centralized networks are considered efficient for some researchers and diffusionists of innovation).

Therefore, the researchers offer to use an interpersonal threshold model approach for this decentralized network. Threshold is the proportion of adopter in the social system that individuals need to adopt an innovation. The collective behavior formed from the threshold plays an important role in individual adoption. This threshold comprehension is more system-based than personal [11].

The application of the interpersonal threshold model in social networks emerges in the form of a combination of social contagion concept concepts on threshold models and interpersonal relationships. If social contagion in this collective behavioral threshold model is measured by the social system in which individuals are combined, interpersonal relationships are benchmarks for measuring social contagion to adopt such innovations [11]. Interpersonal relationships are an important part of social networking. Therefore, in the process of diffusion of innovation, individual exposure to interpersonal networks can increase the rate of adoption of innovation. The exposure of individuals through interpersonal networks is associated with infectious behavior, in which people will be 'infected' to adopt according to what individuals do in interpersonal relationships. interpersonal communication networks if the position of all members of the system is the same, so opinion leaders are not so clear.

The create content of strategy to maximizing the adoption rate of Garbage Clinical insurance can be done by eliminate selective perception by looking at citizens health needs through preventive health action [12]

- Perceived susceptibility, a perception of the possibility of someone experiencing adverse conditions that affect his health. Perceived seriousness, the belief that a person holds about the effects of a disease or certain conditions that cause physical, emotional, financial, and psychological problems. One of the greatest obstacles in a prospective adopter does not feel a threat if the disease comes suddenly and has no health insurance. This misperception is what should be addressed by Indonesia Medika, so that the Garbage Insurance product can be accepted by the people.

- Perceived benefit of taking action, the extent to which a person believes he / she will benefit from the recommended action. This can be done through data collection of diseases that are often experienced by residents, so that can be seen anywhere that can be approached with this approach.

- Perceived barriers to take action, the extent to which treatment or action is assessed as unpleasant, expensive, painful, or irritating. In this approach, it is not a feeling of illness that is considered uncomfortable for the prospective adopter, but rather changing the perception of garbage collection that is complicated and having only a little rubbish becomes more fun by way of more structured garbage dredging programs, such as integrated websites and social media for non- customers who want to donate their garbage.

This is the following strategic communication planning to increase awareness about Garbage Clinical Insurance and preventive health service in a way to increase the number of GCI adopter: 
TABLE III. STRATEGIC COMMUNICATION PLANNING

\begin{tabular}{|l|l|l|l|}
\hline No & \multicolumn{1}{|c|}{$\begin{array}{c}\text { Communication } \\
\text { Tools }\end{array}$} & \multicolumn{1}{|c|}{ Media } & \multicolumn{1}{|c|}{ Activity } \\
\hline 1 & $\begin{array}{l}\text { Public Relations } \\
\text { (service experiencing) }\end{array}$ & Event & $\begin{array}{l}\text { Free Medical } \\
\text { Check Up }\end{array}$ \\
\hline 2 & Public relations & $\begin{array}{l}\text { Intergrating the } \\
\text { website, social } \\
\text { media, apps, } \\
\text { webchat }\end{array}$ & $\begin{array}{l}\text { Launching } \\
\text { "garbage } \\
\text { donation" }\end{array}$ \\
\hline 3 & Public relations & WOM & $\begin{array}{l}\text { Create forum and } \\
\text { health topic in } \\
\text { their daily } \\
\text { conversation and }\end{array}$ \\
\hline 4 & Public relations & $\begin{array}{l}\text { Socialization \& } \\
\text { Counseling }\end{array}$ & $\begin{array}{l}\text { Counseling and } \\
\text { home visit and } \\
\text { having counseling } \\
\text { about healthy diet, } \\
\text { daily activity, } \\
\text { child development }\end{array}$ \\
\hline 5 & Public Relations & Coaching clinic & $\begin{array}{l}\text { Waste } \\
\text { management and } \\
\text { recycle craft }\end{array}$ \\
\hline
\end{tabular}

\section{CONCLUSION}

Before doing the diffusion of innovation, the innovator should be mapping the audience. This is because the network pattern that is formed will largely determine the model of approach that will be used, whether the extension approach is centralized, individual counseling, interpersonal threshold, mass media, or a combination of them. The RT02 / RW05 community has various anomalies compared to other tissue studies, such as open tissue form, but the nature of the individual in it that is closed, making it difficult for the change agent from outside the network to be heterophile.

\section{REFERENCES}

[1] R. Cox, Environmental Communication and The Public Sphere. Thousand Oaks, CA: Sage Publications, 2006.

[2] Riggs, T. and Bonk, M. Everyday Finance: Economics, Personal Money Management, and Entrepreneurship (Vol. 1). Gale Cengage, Pages: 263 265. 2008.

[3] D. Wijono, Manajemen Program Promosi Kesehatan dan Pemberdayaan Masyarakat. Surabaya: Duta Prima Airlangga, 2010.

[4] Singhal, Arvind Diffusion of Innovation. on Littlejohn, Stephen W \& Foss, Karen.A (eds) Encyclopedia of Communication Theory. New York: Sage, 2009.

[5] N.F. Arifiani, "Household Behavior and Attitude Toward Waste Bank in Malang," Jurnal Perencanaan Wilayah dan Kota, BSAPPK Volume 2, No.3. 2014. Pp. 549- 553.

[6] Rothenberg, Richard.B. "Commentary: Sampling in Social Network". INSNA 18 (1). 1994, Pp.: 104-111.

[7] S.P. Borgatti, M.G. Everett and J.C. Johnson, Analayzing Social Network. London: Sage, 2013.

[8] P.J. Carrington, Social Network Research. On Dominguez, Silvia \& Hollstein, Betina (eds.). Mixed Methods Social Network Research, Design \& Applications. NY: Cambridge University Pres, 2014

[9] E.M. Rogers and D.L. Kincaid, Communication Network, Toward a New Paradigm for Research. New York: The Free Press, 1981.

[10] E.M. Rogers, Diffusions of Innovations. Third Edition. New York: Simon \& Schuster Publisher, 1983.

[11] Valente, Thomas. W. "Social Network Threshold in Diffusion of Innovation". Social Network 18. 1996: pp. 69-89.

[12] P. Kotler, N. Roberto and N. Lee, Social Marketing, Improving the Quality of Life, 2nd edition. Thousand Oak, CA: Sage, 2002. 